\title{
Mobilisation of neural structures opens up new possibilities for idiopathic scoliosis treatment
}

\author{
E Santos Leal \\ From 8th International Conference on Conservative Management of Spinal Deformities and SOSORT 2011 \\ Annual Meeting \\ Barcelona, Spain. 19-21 May 2011
}

\section{Background}

Idiopathic Scoliosis (IS) is a progressive disorder with reduced mobility of the spine. This makes corrections difficult or sometimes even inhibits postural changes. Even when correction of frontal or coronal plane deformity seems successful, sagittal correction mostly is not addressed appropriately. This might be due to functional tethering of the spinal cord or even of peripheral neural structures. This explains the lack of success when trying to correct sagittal plane deformity with the help of stretching exercises. Purpose of this study was to test how the release of these structures may relax lordotic tension in the thoracic area.

\section{Materials and methods}

Finger - floor distance and sciatic slump was tested in 25 patients before and after a session of physiotherapy using neural tension exercises (Butler) [1,2].

\section{Results}

Significant differences have been achieved with the help of these techniques $(16-21 \mathrm{~cm}$ at the start independent of patient age / 3-0 cm at the end) with improved kyphosation at the same time.

\section{Conclusions}

While in sole stretching of the hamstrings the sagittal profile cannot be improved, neurodynamics provide an improvement of this deformity. Neurodynamics therefore seem to be a useful add on in the physical treatment of IS.

Published: 27 January 2012

Pysiotherapiecenter, Iserlohn, Germany

(C) 2012 Leal; licensee BioMed Central Ltd. This is an open access article distributed under the terms of the Creative Commons Attribution License (http://creativecommons.org/licenses/by/2.0), which permits unrestricted use, distribution, and reproduction in any medium, provided the original work is properly cited.
References

1. Coppleters MW, Butler DS: In defense of neural mobilization. J Orthop Sports Phys Ther 2001, 31(9):520-1.

2. Kenton G: Support for neural tissue mobilization. J Orthop Sports Phys Ther 2001, 31(9):519-520; author reply 522.

\section{doi:10.1186/1748-7161-7-S1-O56}

Cite this article as: Leal: Mobilisation of neural structures opens up new possibilities for idiopathic scoliosis treatment. Scoliosis 2012 7(Suppl 1): O56.

Submit your next manuscript to BioMed Central and take full advantage of:

- Convenient online submission

- Thorough peer review

- No space constraints or color figure charges

- Immediate publication on acceptance

- Inclusion in PubMed, CAS, Scopus and Google Scholar

- Research which is freely available for redistribution 